\title{
Production and Economic Feasibility of Hydroponics Maize Fodder on Performance of Piglets
}

\author{
Sujaya Upreti ${ }^{*}$, Ram P. Ghimire ${ }^{1}$, Megh Raj Tiwari ${ }^{2}$ and Niraj Banskota ${ }^{3}$ \\ ${ }^{1}$ Pasture and Fodder Division, NARC, Khumaltar, Lalitpur \\ ${ }^{2}$ National Animal Science Research Institute, NARC, Khumaltar, Lalitpur \\ ${ }^{3}$ Swine and Avian Research Programme, NARC, Khumaltar, Lalitpur
}

\section{*CORRESPONDENCE:}

Sujaya Upreti

Pasture and Fodder Division, NARC, Khumaltar, Lalitpur

Email: sujayaupreti824@hotmail.com

ISSN : 2382-5359(Online), 1994-1412(Print)

DOI:

https://doi.org/10.3126/njst.v20i1.39445

\section{ACCESS THE ARTICLE ONLINE}

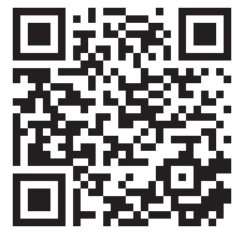

\section{CONFILICT OF INTEREST: None}

Copyright: The Author(s) 2020. This is an open access article under the $\underline{\text { CC BY license. }}$

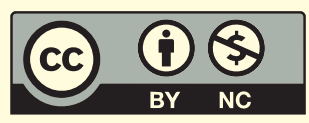

\begin{abstract}
An experiment was conducted to evaluate the effects of hydroponics maize fodder on growth and nutrient digestibility of weaned piglets from July $1^{\text {st }}, 2017$ to August $11^{\text {th }}, 2017$, for six weeks. The experiment consisted of 75 days old, 15 crossbreed piglets (Duroc x Nagpuri \& Duroc) in a Completely Randomized Design with three treatments and five replications. Treatment 1 (T1) contained 100\% concentrate feed, Treatment 2 (T2) 90\% concentrate feed and 10\% hydroponics maize fodder and Treatment 3 (T3) 80\% concentrate feed and $20 \%$ hydroponics maize fodder in the diet. The study revealed that hydroponics maize fodder contained DM 13.80\%, CP $12.54 \%$, NDF 47.04\%, and ADL 16.51\%. The treatments had non-significant effect $(\mathrm{P}>0.05)$ on daily weight gain, final weight and feed conversion ratio of the piglets. However, piglets fed with $90 \%$ concentrate and $10 \%$ hydroponics maize fodder had the highest final weight $(35.8 \pm 5.0$ $\mathrm{kg})$, while the lowest $(33.6 \pm 5.00 \mathrm{~kg})$ was recorded in piglets fed with $80 \%$ concentrate and $20 \%$ hydroponics maize fodder. The cost of hydroponics maize fodder production was Rs. 20.62 per $\mathrm{kg}$, which was higher than the cost in the Indian context. The difference in Feed Conversion Ratio (FCR) was also not significant. However, piglets fed with T2 $(1: 2.58)$ diet recorded higher FCR than T3 $(1: 2.56)$ and T1 (1:2.51). In conclusion, the inclusion of hydroponics maize fodder in piglets diet appeared promising in growth, nutrient digestibility and cost of production.
\end{abstract}

Keywords: Concentrate feed; randomized design; nutrient content; piglets' growth; production cost,

\section{INTRODUCTION}

Piggery is popular for income generation and household consumption in Nepal due to its sound economic return and faster growth with a better feed conversion ratio. Due to its multiparous and fast-growing characters, piggery needs a more considerable amount of feed (Mahato 2013; Upadhyaya 2014). Pig is the most efficient converter of feed into the meat with an excellent dressing percentage, ranging from 70 to $75 \%$, compared to other farm animals. Pig's feed conversion ratio is 1:3 to 1:4, depending on the type of feed offered (Upadhyaya 2014). Nevertheless, their production is fronting constraints of increasing production cost, significantly rising cost of feed ingredients and compound feed, and competition between human food and pig feeds (Shrestha, 2014). In this context, feeding green fodder to the pigs is a recently emerging concept globally. The green fodder deficit is a major constraint of Nepal's ruminant production systems, 
which happens also in piggery. There is a shortage of green fodder due to the small landholding size and land fertility status (DLS-NAFLQML, 2019).

Furthermore, natural calamities, such as flood, drought landslide and cold waves impact the fodder production in open fields demanding the need for enclosed fodder farming, like hydroponic farming, to save lives during the emergency period. The hydroponic fodder feeding practice is more suitable to the urban and peri-urban areas where the land is limited. It is best suited to semi-arid, arid and drought-prone regions of the world, suffering from chronic water shortage, or in areas where irrigation infrastructure does not exist (Bakshi 2018).

Previously, pork was preferred by certain tribes of people, such as Rai, Limbu, Magar, Sunuwar, Tamang, Majhi, Kami, Tharu, etc. But these days, most of the Nepal's population prefers to consume the pork and therefore has increased the annual national demand of pork across the country. Pig is competing for human food in the rural and urban areas of Nepal. They require cereal grains and legumes in their diet as they are monogastric animal. Therefore, if pigs are only fed with cereal grains, there will be a shortage of food to the human being that ultimately challenges the nation's food security. Currently, there are two situations related to pig farming in the country, (1) the cost of concentrate feed is increasing every year by 15 to 20 percent (Nepal Feed Industries Association, 2019) and (2) the annual pig population of the improved breeds is increasing by 7.477 percent (MoALD 2075). These two situations demanded to increase feed grain production and find out the possibilities to reduce the dependency of pigs on costly cereal grains by using the alternative feed components in their diet.

The need for alternative ways to grow fodder for farm animals has been realized to support animals during regular and emergency feedings (Sneath \& Mclntosh 2003; Naik et al. 2011). Some farmers in Nepal have established the hydroponic fodder production system, a soil less culture and alternative to conventional green fodder production. In current farmers' practices, as they reported, the cereal or forage seeds are soaked in water or nutrient solution for overnights and put in a plastic tray; the seeds sprout within 12 hours, and grow about 20-25 cm (8-10 inch) high and form fodder mat within 7 days, very similar to "Jamara" and the whole mass is offered to animals. Swine and Avian Research Programme at Khumaltar have initiated hydroponic maize fodder feeding to the piglets, but the result was not conclusive. There are several cereal crops selected as suitable for hydroponic fodder production by several workers. Some of them are barley (Reddy et al. 1988) oat, wheat (Snow et al. 2008); sorghum, alfalfa, cowpea (AI-Karaki et al. 2012) and maize (Naik et al. 2011; Naik et al. 2014). Studies have proved that the nutrient content and digestibility of hydroponic fodders are superior to particular typical cereal and leguminous fodders, such as Berseem and clover in terms of nutrients availability, such as OM, CP, EE and NFE content (Reddy et al. 1988, Pandey \& Pathak 1991; Naik et al. 2012a).

Therefore, the objectives of this study were to determine the effect of feeding hydroponics maize fodder (HMF) along with concentrate on growth and nutrient digestibility of weaned piglets, and to know the economic feasibility of hydroponics maize fodder production in Nepalese condition.

\section{MATERIALS AND METHOD}

\subsection{Study site, Design and Treatments}

The experiment was carried out in the farm of Swine and Avian Research Programme, NARC, Khumaltar, during July 1 $1^{\text {st }}, 2017$ to August $11^{\text {th }}, 2017$ for six weeks. A total of 15 , weaned, crossbred and pure piglets (Duroc x Nagpuri cross \& Duroc pure breed) of 75 days age and similar sex as male or female and body weight were used in the experiment. The experiment consisted of three treatments replicated five times in a Completely Randomized Design. Treatment 1 (T1) contained $100 \%$ concentrate feed of $20 \%$ crude protein, Treatment 2 (T2) $90 \%$ concentrate feed and $10 \%$ hydroponics maize fodder (by weight), and Treatment 3 (T3) $80 \%$ concentrate feed and $20 \%$ hydroponics maize fodder (by weight) in the diet.

\subsection{Production of Hydroponics Maize Fodder}

Hydroponics maize fodder was produced in a $12 \mathrm{ft}$ long, $8 \mathrm{ft}$ wide and $9 \mathrm{ft}$ high poly-house of Pasture and Fodder Division, NARC, Khumaltar. The automatic fogger was used for maintaining relative humidity $(90 \%)$ and provide irrigation. Clean and unbroken seeds of maize (Zea mays) were soaked in tap water overnight and kept in a jute sack for two days. Germinated seeds were placed in clean, plastic antifungal trays of 2'6" length and 1'3" width and 6" height. The trays were kept inside the poly house. The plants were allowed to grow for 10 days, until they reached to $20-30 \mathrm{~cm}$ height, and harvested on the 11th day. Hydroponics maize fodder, a mat of germinated seeds embedded in their white roots and green shoots, was used for the experimental diets and fed to the piglets. The green fodder samples were also taken on the eleventh day to determine the dry matter and nutrient content, such as Crude Protein (CP), Neutral Detergent Fibre (NDF), Acid Detergent Fibre (ADF), Acid Detergent Lignin (ADL), Hemi Cellulose (HC) and Cellulose (AoAC 1990). 


\subsection{Economics of Hydroponics Maize Fodder Production}

The cost of Hydroponic Maize Fodder (HMF) production was calculated by adding the cost of trays only in case of fixed cost. The cost of seed (Rs. 30/kg), electricity (Rs.12/ unit) and labor (Rs. 46.96/tray) was included for the variable costs. The costs of each expense were recorded, and the cost of hydroponics fodder maize production was calculated. The maize fodder yield was calculated from 0.5 $\mathrm{m}^{2}$ quadrate.

\subsection{Feeding and Management}

The piglets were drenched with Albendazole (@ $5 \mathrm{mg} / \mathrm{kg}$ body weight) and dipped into Malathion (0.5\%) suspension against internal and external parasites, respectively, one week before the commencement of the experiment.

The experimental piglets, placed each in individual pan, were offered feed twice daily (Morning \& Evening) on the basis of dry matter requirement as adapted in the farm, while clean drinking water was provided ad-lib. Dry matter requirement of the piglets was calculated by considering the requirements recommended by NRC (2012). The feeding practices used were, control groups fed with concentrate feed $(20 \%$ CP) without hydroponics fodder (T1) and the other two treatments were fed with concentrate feed $(20 \%$ CP) of which $10 \%$ (T2) and $20 \%$ (T3) by weight replaced by hydroponics maize fodder.

\subsection{Growth and Feed Intake of Piglets}

Daily and weekly growth rates of the piglets were observed. Daily weight gain $(\mathrm{kg})$ was determined by subtracting the initial body weight from the final body weight and was divided by days of experimental period. Feed intake was obtained by subtracting the leftover feed by each animal from the total quantity of feed served daily at evening and morning (i.e. in $24 \mathrm{~h}$ ). Feed conversion ratio (FCR) was calculated as the quantity of feed $(\mathrm{kg})$ consumed to gain a unit of live-in-weight $(\mathrm{kg})$.

\section{FCR=Feed Intake/Weight Gain}

\subsection{In-vivo Nutrient Digestibility Determination}

A seven-day nutrient digestibility experiment was conducted on the test animals at the last week of the feeding trial, leaving the feeding schedule as such. Faeces were collected from the individual animal immediately after defecation. The experimental diet samples from all the three treatments and all the fecal samples were dried and further processed for analysis of crude protein (CP), crude fiber (CF) and ether extract (EE) and ash contents using the procedure of AoAC (1990). The nitrogen-free extract (NFE) contents of the samples were obtained using the equation:

$$
\mathrm{NFE}=100-(\mathrm{CF}+\mathrm{CP}+\mathrm{EE}+\mathrm{Ash}) \%
$$

The feed offered and refusals were recorded daily. The body weight changes of the experimental animals were recorded at daily and weekly intervals. Average Daily Gain (ADG) and Feed Conversion Ratio (FCR) were calculated using data recorded daily. The feed samples, both concentrate and rough ages, were analyzed for proximate analysis (NRC 2012). Treatment means were calculated.

\subsection{Data Analysis}

Data were analyzed by using GenStat 5.3.2 statistical software.

\section{RESULTS AND DISCUSSION}

\subsection{Yield and Other Characters of Hydroponics Maize Fodder}

The mean height of Hydroponic Maize Fodder (HMF) was recorded as $27.65 \pm 0.34 \mathrm{~cm}$ in 11 days (Table 1), which was within the range $(11-30 \mathrm{~cm})$ given by Naik et al. (2015). Leaf color was, yellow-green. Other studies stated that depending upon the type of grain, the hydroponics fodder looks like a mat at the end of the germination period of about 8 days consisting of germinated seeds embedded in their white roots and green shoots (Snow et al. 2008; Naik et al. 2014). In this experiment, one kg maize grain produced $5 \mathrm{~kg}$ fresh HMF, which was lower than the report (8-10 kg) of Naik et al. (2013b). Several authors reported that the type of crops mainly influence the fresh yield and dry matter (DM) content of the hydroponic fodder. Besides, days of harvesting, degree of drainage of free water before weighing, type and quality of seed, seed rate, seed treatment, water quality, $\mathrm{pH}$, irrigation frequencies, nutrient solution used, light, growing period, temperature, humidity, clean and hygienic condition of the greenhouse also affect the fresh yield and dry matter (Trubey \& Otros 1969; Sneath \& McIntosh 2003; Dung et al. 2010a; Fazeli et al. 2011; Naik 2012b; Naik 2013a; Naik 2013b).

Table 1. Plant height, color and yield of hydroponics maize fodder

\begin{tabular}{|l|l|c|c|}
\hline SN & Attributes & Values & Standard Error of Mean (SEM) \\
\hline 1 & Plant height $(\mathrm{cm})$ & 27.65 & 0.34 \\
\hline 2 & Leaf colour & Yellow-green & - \\
\hline 3 & Yield $\left(\mathrm{kg} \mathrm{tray}^{-1}\right)$ & 3.09 & 0.06 \\
\hline
\end{tabular}

\subsection{Nutrient Composition of Hydroponic Maize Fodder}

The fresh dry matter (FDM) content of hydroponic maize fodder (HMF) was $12.39 \pm 0.55 \%$ (Table 2), which was similar to the result of Naik et al. (2015) (11-14\%), but less than reported (25\%) by Adebiyi et al. (2018). Decreased starch content during sprouting sometimes declines the 
FDM (Naik et al. 2015). HMF had shown adequate crude protein $(\mathrm{CP})$ content $(12.55 \%)$, which was higher than that of $\mathrm{CP}$ content of the used maize grain (7.38\%) in this study, but, lower than reported $(13.57 \%$ \& $13.75 \%)$ by Naik et al. (2015) and Adebiyi et al. (2018), respectively. Several authors reported that hydroponics fodder's nutrient content is superior to certain common non-leguminous fodders, but comparable to leguminous fodder in terms of available OM, CP, EE and NFE content (Reddy et al. 2014, Pandey \& Pathak 1991; Naik et al. 2012a). The recorded fibre fractions were $47.04 \pm 9.99 \%$ and $23.16 \pm 3.40 \%$ for NDF and ADF, respectively (Table 2). Naik et al. (2015) reported that the increase in the content of $\mathrm{CF}, \mathrm{NDF}$ and $\mathrm{ADF}$ and decrease in the NFE and NFC might be attributed to the increase in the number and size of cell walls for the synthesis of structural carbohydrates (cellulose and hemicellulose).

Table 2. Nutrient composition of hydroponic maize fodder

\begin{tabular}{|l|l|c|c|}
\hline SN & Parameters & Nutrient Content (\%) & SEM \\
\hline 1 & Fresh dry matter (FDM) & 12.39 & 0.55 \\
\hline 2 & Crude protein (CP) & 12.55 & 1.79 \\
\hline 3 & Neutral detergent fiber (NDF) & 47.04 & 9.99 \\
\hline 4 & Acid detergent fiber (ADF) & 23.16 & 3.40 \\
\hline 5 & Acid detergent lignin (ADL) & 16.51 & 2.63 \\
\hline 6 & Hemi-cellulose (HC) & 23.87 & 11.16 \\
\hline 7 & Cellulose (C) & 6.64 & 3.22 \\
\hline
\end{tabular}

\subsection{Feed Intake, Growth of Piglets and Profitability}

Dietary treatments had non-significant effects $(\mathrm{P}>0.05)$ on final weight, average daily gain and feed conversion ratio of the piglets. Piglets with T1 (100\% concentrate feed) had the highest total feed intake $(43.59 \mathrm{~kg})$, followed by T2 (90\% concentrate and 10\% hydroponics maize fodder) $(43.04 \mathrm{~kg})$ and T3 $(80 \%$ concentrate and $20 \%$ hydroponics maize fodder) $(40.79 \mathrm{~kg})$ (Table 3). The weight gain was also obtained non-significant $(\mathrm{P}>0.05)$. The range of final body weight gain was 16.7 to $18.3 \mathrm{~kg}$. Accordingly, the average daily gain (ADG) was ranged from 0.35 to 0.43 kg. Our results contradicted with the report of Adebiyi et al. (2018) who found feed intake and weight gain highest $(\mathrm{P}<0.05)$ in weaned piglets fed with the concentrate diet $\left(\mathrm{Conc}_{100}\right)$, while the lowest intake in animals fed with hydroponics maize fodder (Hydroponic Maize Fodder $_{100}$ ). In the present study, the feed conversion ratio (FCR) was also non-significantly different. However, little variations on FCR were found. Again, in another study by Adebiyi et al. (2018), FCR was improved $(\mathrm{P}<0.05)$ in pigs fed $\mathrm{Con}_{100}$ and $\mathrm{Con}_{50} \mathrm{HM}_{50}$. Hydroponic sprouts are rich sources of bioactive enzymes and contain grass juice ingredients that improve livestock performance (Naik et $a l ., 2013)$. Sprouting of grains has resulted in an increase in the quantity and quality of protein, sugars, minerals and vitamins (Naik et al., 2015). It could be the reason for the non-significant differences between different dietary treatments. It had revealed that the HMF can successfully replace $20 \%$ of the concentrate.

The study showed the possibility of replacement of concentrate feed by HMF up to $20 \%$, which decreased also the daily feed cost (Table 3). The finding was similar to the findings of Adebiyi et al. (2018), who reported the lowest feeding cost and highest profit in weaned pigs fed with a dietary mixture of HMF. In terms of economic efficiency, it was more profitable (low feed cost per weight gain) to feed piglets T2 (131.36) diet as compared to T3 (131.45) and T1 (142.91). The result was similar to the report of Adebiyi et al. ( 2018) who found the feed cost per $\mathrm{kg}$ weight gain more profitable in $\mathrm{Conc}_{50} \mathrm{HM}_{50}(228.01)$ than $\mathrm{Con}_{100}$ (316.4) and $\mathrm{HM}_{100}(-446.91)$.

Table 3. Feed intake, growth of piglets and benefits of complementing hydroponics maize fodder in diet of piglets

\begin{tabular}{|c|c|c|c|c|c|c|c|c|}
\hline SN & Parameters & T1 & T2 & T3 & SEM & P-value & LSD & $\mathrm{CV}$ \\
\hline 1 & Initial Body Weight (kg) & 16.80 & 17.50 & 16.95 & 2.35 & NS & 5.44 & 21.8 \\
\hline 2 & Final Body Weight (kg) & 34.7 & 35.8 & 33.6 & 5.00 & NS & 11.52 & 22.8 \\
\hline 3 & Weight Gain (kg) & 17.9 & 18.3 & 16.7 & 2.10 & NS & 6.84 & 26.6 \\
\hline 4 & Average Daily Gain (kg) & 0.42 & 0.43 & 0.35 & 0.070 & NS & 0.162 & 26.6 \\
\hline 5 & Carcass Weight (kg) & 15.2 & 15.5 & 14.2 & 2.52 & NS & 5.81 & 26.6 \\
\hline 6 & Feed Conversion Ratio & 2.51 & 2.58 & 2.56 & 0.36 & NS & 1.185 & 31.9 \\
\hline 7 & Feed Intake (DM kg) & 43.59 & 43.04 & 40.79 & & & & \\
\hline 8 & Feed Cost $/ \mathrm{kg}$ & 50.00 & 47.42 & 45.69 & & & & \\
\hline 9 & Feed cost weight ${ }^{-1}$ gain $(\mathrm{kg})$ & 142.91 & 131.36 & 131.45 & & & & \\
\hline
\end{tabular}




\subsection{Parasitic Status of Piglets}

The faecal samples were tested for parasitic load at the beginning and the end of the experiment at the Animal Health Research Division (AHRD) of NARC, Khumaltar. The parasites that appeared in all three treatments at the end of the experiment were Coccidosis spp. (1 piglet), Ascarids spp. (2 piglets) and Trichuris spp. (1 piglet), which were, however, at sub-clinical level.

\subsection{Nutrient Digestibility of Piglets}

Inclusion of hydroponic maize fodder up to $20 \%$ in piglets ration did not negatively impact nutrient digestibility. The feed provided to the animal was nutritious as the $\mathrm{CP}$ content was high (15-16\%). Crude Protein (16.68\%) and Ash (27.16\%) digestibility were found positive $(\mathrm{P}>0.05)$ in concentrate feed (T1) as presented in Table 4, which was lower than Adebiyi et al. (2018), where Conc ${ }_{100}$ had $70.51 \%$ CP. The CF content was higher in T2 $(31.20 \%)$, followed by T3 (23.00\%) and T1 (17.80\%) in this study, which showed lower crude fibre utilization in monogastric animals. Feeding of hydroponics fodder increased the digestibility of the nutrients, which could be attributed to the fodder's tenderness (Naik et al., 2014). Chung et al. (1989) reported that highly soluble protein and amino acids in response to the early plant growth and enzymatic transformations of sprouted grains are responsible for improved digestibility.

Table 4. Nutrient digestibility of piglets fed with hydroponics maize fodder

\begin{tabular}{|l|l|l|l|l|l|l|l|l|}
\hline SN & $\begin{array}{l}\text { Parameters } \\
\left(\begin{array}{l}\text { T) } \\
\text { T1 }\end{array}\right.\end{array}$ & T2 & T3 & SEM & P-value & $\begin{array}{l}\text { LSD(0.05 } \\
\text { level) }\end{array}$ & CV \\
\hline 1 & FDM & $33.49^{\mathrm{a}}$ & $30.34^{\mathrm{b}}$ & $27.93^{\mathrm{c}}$ & 0.26 & $<0.001$ & 0.85 & 1.90 \\
\hline 2 & CP & 16.68 & 16.35 & 15.54 & 0.63 & NS & 2.08 & 8.80 \\
\hline 3 & CF & $17.80^{\mathrm{c}}$ & $31.20^{\mathrm{a}}$ & $23.00^{\mathrm{b}}$ & 2.26 & 0.009 & 7.36 & 21.0 \\
\hline 4 & Ash & 27.16 & 24.92 & 23.74 & 1.38 & NS & 4.52 & 12.3 \\
\hline 5 & OM & 72.84 & 75.08 & 76.26 & 1.38 & NS & 4.52 & 4.20 \\
\hline
\end{tabular}

T1: $100 \%$ concentrate feed, T2: $90 \%$ concentrate feed $+10 \%$ hydroponics maize fodder (HMF) and T3: 80\% concentrate feed $+20 \%$ HMF.

\subsection{Cost of Hydroponics Maize Fodder Production}

The cost of production per kg of HMF was NRs. 20.62 (Table 5), which was much higher compared to Naik et al. (2013) (NRs. 5.60/kg), Jemimah et al. (2015) (NRs. 3.00/ $\mathrm{kg}$ ) and Gunasekaran et al. (2017) (NRs. 4.50/kg) due to higher maize seed cost in Nepal than India. The price of maize seed, electricity and labor costs were NRs. 14.50/ kg, NRs. 4.00/unit and NRs.4.50/tray, respectively, in the study of Jemimah et al. (2015). The cost depends upon the locations, market price and accessibility. Gunasekaran et al. (2017) reported that even though hydroponics fodder is costlier, it can be effectively utilized for feeding animals during adverse situations, such as drought, flooding, cold wave etc at a reasonable cost.

Table 5. Cost per kg of hydroponics maize fodder production

\begin{tabular}{|l|l|l|}
\hline \multicolumn{1}{|c|}{ SN } & \multicolumn{1}{c|}{ Input } & \multicolumn{1}{c|}{ Cost (NRs) } \\
\hline 1 & Fixed Cost & \\
\hline 1.1 & Tray & 0.84 \\
\hline 2 & Operational Cost & \\
\hline 2.1 & Seed & 6 \\
\hline 2.2 & Electricity & 0.25 \\
\hline 2.3 & Labor & 13.53 \\
\hline & Total cost kg-1 & 20.62 \\
\hline
\end{tabular}

\section{CONCLUSION}

The study revealed that replacing up to $20 \%$ of the concentrate feed with HMF in the ration of piglets seems to be economical. It reduced the feed cost by (Rs. 45.69/ $\mathrm{kg}$ ) without altering the daily weight gain. This piglet feeding strategy helped to reduce the use of concentrate in pig feed, which can be a milestone for diminishing the competition in human food and ultimately improving food security. Hydroponics maize fodder feed led to a decrease in the total daily feeding cost of experimental rations compared to the sole concentrate diet. Thus, there seems to be a great potential for using hydroponic technology for fodder production in pig farming to reduce the feed cost and cost of pork production. However, further research is needed to see the results on addition of more and different fodders in the piglets' ration.

\section{ACKNOWLEDGEMENT}

The authors are thankful to the Nepal Agricultural Research Council (NARC), Singha darbar, Plaza for providing financial support to conduct the study. The authors are also very grateful to Mr Damodar Neupane, Coordinator of Swine and Avian Program, due to providing experimental piglets and managerial supports throughout the experimental period. Similarly, sincere thanks go to Mr Bashanta Kumar Shrestha for appreciable cooperation in feed analysis and Ms. Sushila Pandit GC, Mr. Bishnu Mishra, Ms. Sabitra Acharya and Mr. Kumar Thapa for record-keeping during the experiment. 


\section{REFERENCES}

1. Adebiyi, O. A., A.T. Adeola, O.A. Osinowo, D. Brown and J.W. NgAmbi. 2018. Effects of feeding hydroponics maize fodder on performance and nutrient digestibility of weaned pigs. Applied Ecology and Environmental Research. 16(3): 2415-2422.

2. AoAC (Association of Analytical Communities). 1990. Official Method of Analysis.

3. Bakshi, M.P.S., M.W. Harinder and P.S. Makkar. 2018. Hydroponic fodder production: A critical assessment. Feedipedia Animal Feed Resources Information System-INRA CIRAD AFZ and FAO.

4. Chung, T.Y., E.N. Nwokolo and J.S. Sim. 1989. Compositional and digestibility changes in sprouted barley and canola seeds. - Plant Foods for Human Nutrition. 39: 267-278.

5. Department of Livestock Service (DLS)-NAFLQML. 2019. Balance sheet of animal feed and forage seed of Nepal and impact study of forage mission program. Pub. NAFLQML, Hariharbhawan, Lalitpur.

6. Dung D.D., I.R. Godwin and J.V. Nolan. 2010a. Nutrient content and in Sacco degradation of hydroponic barley sprouts grown using the nutrient solution or tap water. J. Anim. Vet. Adv. 9(18): 2432-2436.

7. Fazaeli, H., H.A. Golmohammadi, A.A. Shoyayee., N. Montajebi and Sh. Mosharaff. 2011. Performance of feedlot calves fed hydroponics fodder barley. $J$. Agric.Sci.Technol. 13: 365-375.

8. Gunasekaran, S.C. Valli and C. Bandeswaran. 2017. Production of low cost hydroponic maize fodder to mitigate fodder shortages for livestock during drought conditions. http://pashusandesh.com/hydroponicmaize.

9. Jemimah, E.R., P.T. Gnanaraj, T. Muthuramalingam, M. Babu and A. Sundharesan. 2015. Hydroponic Green Fodder Production. Tanuvas Experience.

10. Karki, A.I., N. Ghazi and M. AI-Hashimi. 2012. Green fodder production and water use efficiency of some forage crops under hydroponic condition. International Scholarly Research N e t w or k, DOI:10.5402/2012/924672.

11. Mahato, G. 2013. Production status of pig in Nepal, March 14, 2013. www.

$\mathrm{S}$ c r i b d/ doc/130331507/Production status of pig in Nepal.

12. Ministry of Agriculture and Livestock Development.
2075. Livestock Census, 2075.

13. Naik, P.K. and N.P. Singh. 2013. Hydroponics fodder production: an alternative technology for Sustainable livestock production against impending climate change. In: Compendium of Model Training Course "Management Strategies for Sustainable Livestock Production against Spending Climate Change", held during November 18-25, 2013. Southern Regional Station, National Dairy research Institute, Adugodi, and Bengaluru, India.

14. Naik, P.K., B.K. Swain and N.P. Singh. 2015. Hydroponics: It's Feasibility as an Alternative to Cultivated Forages and Pasture.

15. Naik, P.K., R.B. Dhuri and N.B. Singh. 2011. Technology for production and feeding of hydroponics green fodder. Extension Folder No.45/2011, ICAR Research Complex for Goa, India.

16. Naik, P.K., R.B. Dhuri., B.K. Swain. and N.P. Singh. 2012a. Nutrient changes with the growths of hydroponics fodder maize. Indian Journal Animal Nutrition. 29: 161-163.

17. Naik, P.K., R.B. Dhuri, M. Karunakaran, B.K. Swain and N.P. Singh. 2014. Effect of feeding hydroponics maize fodder on digestibility of nutrients and milk production in lactating cows. Indian Journal of Animal Sciences. 84: 880-883.

18. Naik, P.K., S.P. Gaikwad, M.J. Gupta, R.B. Dhuri, G.M. Dhumal and N.P. Singh. 2013b. Low cost devices for hydroponic fodder production. Indian Dairyman.

19. Naik, P.K. 2012b. Effect of soaking time on yield of hydroponics maize fodder. (Unpublished).

20. Naik, P.K. 2013b. Yield and dry matter content of hydroponics maize sprouts. (Unpublished).

21. National Research Council (NRC). 2012. Nutrient Requirement of Swine. Pub National Academic Press, Washngton D.C., USA.

22. NFIA. 2019. Nepal Feed Industries Association, Kathmandu, Nepal.

23. Pandey, H.N. and N.N. Pathak. 1991. Nutritional evaluation of artificially grown barley fodder in lactating crossbred cows. Indian Journal of Animal Nutrition. 8:77-78.

24. Paudel, K.C and B.N. Tiwari. 1992. Fodder and Forage. Sustainable livestock production in the mountain agroecosystem of Nepal. Food and Agriculture Organization 
of the United Nations.

25. Reddy G.V.N., M. R. Reddy and K.K. Reddy.1988. Nutrient utilization by mulch cattle feed on rations containing artificially grown under fodder. Indian Journal of Animal Nutrition. 5:19-22.

26. Reddy, Y.R. 2014. Hydroponic Fodder Production. http://www.authorstrem.com/Presentation/Kiran Reddy 526438-2376257-hydroponic-fodderproduction.

27. Shrestha, B.S., P. Pathak and S.P. Paudel. 2014. Policy and enabling environment to promote pig and pork industries in Nepal. In: Proceedings of the First National Workshop on Pig and Pork Industry in Nepal.

28. Sneath, R. and F. Mclntosh. 2003. Review of hydroponic fodder production for beef cattle. Queensland government. Department of Primary Industries, Dalby, Queensland.

29. Snow, A.M., A. E. Ghal and A. Snow. 2008. A comparative assessment of hydroponically grown cereal crops for the purification of aquaculture waste water and the production of fish feed. American Journal of Agricultural and Biological Sciences. 3: 364-378.

30. Trubey, C.R. and Y. Otros. 1969. Effect of light, culture solution, and growth period in growth and chemical composition of hydroponically produced oat seedlings. Agron. J. 61: 663-665.

31 Upadhyaya, M. 2014. Safe Pork Production: Biosecurity Measures Meeting Food Safety in Nepal. Proceedings of the First National Workshop on Pig and Pork Industry in Nepal. 